\title{
THE IMPLEMENTATION OF AUTHENTIC ASSESSMENT IN MA DI PUTRA NURUL HAKIM IN THE ACADEMIC YEAR 2017/2018
}

\author{
by: \\ Imansyah \\ I Made Permadi Utama \\ Baiq Sumarni \\ Dosen Pendidikan Bahasa Inggris FPBS IKIP Mataram
}

\begin{abstract}
:
This research was conducted in attempt to analyze and describe the types of authentic assessment implemented by the EFL Teachers at MA DI PUTRA NURUL HAKIM. This research applied a descriptive research design since it was aimed at analyzing and describing the types of authentic assessment practiced by the EFL teachers in English classes in MA DI PUTRA NURUL HAKIM. The method of gathering the data was observation supported with document study and interview to get more deeply. In relation to the problem raised, the current study found that there were various types of authentic assessment used by the EFL teachers. They were oral presentations and dramatizations, story telling, reading aloud,demonstration, constructed response items, writing samples, and peer assessment. The researcheralso found that the EFL teachers integrated one skill with others since one single method of assessment can be used to assess more than one skill, and one skill was assessed by using some types of assessement.
\end{abstract}

Key word: authentic assessmeent

\section{BACKGROUND OF THE STUDY}

The main purpose of classroom instruction is to help students achieve a set of intended learning goals. These goals should typically include desired changes in the intellectual, emotional, and physical spheres. When classroom instruction is viewed in this light, assessment becomes an integral part of the teaching-learning process. The intended learning outcomes are established by the goals, the desired changes in students are brought about by the planned learning activities, and the students learning progress is periodically assessed by tests and other assessment devices.
There have been notable transitions in the assessment of student achievement at present times which can be greatly attributed to the fact that today's students are facing a world that demands new knowledge and abilities. Nowadays, it is of utmost importance for students not only to understand the basics but also to think critically, to analyze, and to make inferences (Black, P., \&Wiliam,D., 2006). Achievement of such skills will require changes in assessment at the school and classroom level, on top of new methodologies to large-scale, high-stakes assessment.

The shift to authentic assessment is based upon the principle that 
assessment should first and foremost sustain the needs of learners. Traditional assessment methods use paper-andpencil tests to gauge students' performance which cannot adequately assess aptitude (Nitko, 2004). Therefore, a traditional assessment that is made of secretive tests, proxy items and scores that have no palpable meaning or efficacy destabilize both the educators' capability to enhance their instruction and the students' aptitude to perk up their performance.

The importance of authentic assessment has been recognized. It can be seen from many researches have been conducted on it. Marhaeni (2005) conducted a research on the effect of portfolio on students' achievement motivation to improve students' writing skill. The samples were the English students at English Education Department in Undiksha. In her research, she found that students were assessed by using portfolio got higher score than the students who were assessed by using conventional assessment. Suparjana (2010) did research on the development of performance assessment instrument for speaking skill. The subjects were the English teachers in Karangasem. He found that teachers dealt with the problems of understanding and implementing the authentic assessment and performance assessment, as the type of authentic assessment, especially in speaking skill. About $77.78 \%$ indicators were not assessed through performance assessment, and $72.22 \%$ of the teachers did not use the appropriate forms of assessment.Kusumadinata conducted the same research on the developing performance assessment. She developed performance assessment for reading skill. The subjects were the English teachers Tabanan. She also found that the teachers did not understand about performance assessment.

From the above empirical researches, it can be said that almost all of the empirical researches above were concerned with the contribution of certain type of authentic assessment toward students' skills, and most of them were designed in descriptive quantitative research which were taken into experimental research. In the present research, it was meant to describe and figure out the phenomenon of the use of authentic assessment implemented by the EFL teachers at MA DI PUTRA NURUL HAKIM, without looking at its contribution toward the students' skills.

\section{THEORETICAL REVIEW}

\section{Authentic Assessment}

According to $\mathrm{O}^{\prime}$ Malley\& Pierce (1996), there are seven types of authentic assessment, they are:

1) Oral interviews

Teacher asks students questions about personal background, activities, readings, and interests. And then students respond orally to questions

2) Story or text retelling

Teacher asks students to retell main ideas or selected details of text experienced through listening or reading.

3) Writing samples

Students are asked to generate narrative, expository, persuasive, or reference paper.

4) Project and exhibitions 
Students are asked to complete project in content area, individually or group.

5) Experiments or demonstration Students complete experiment or demonstrate use of materials.

6) Constructed-response items Students respond in writing to open-ended questions.

7) Teachers observations

Teacher observes students attention, response to instructional materials, or interactions with other students.

8) Portfolios

Focused collections of students work to show progress over time. It includes samples of student work, usually selected by the student or by student and teacher to represent learning based on instructional objectives.

According to Nitko, Anthony J

(2004: 243), there are some types of performance assessment, they are:

1. Structured, On-Demand Tasks Structured tasks; assessing students performance in many different settings, including those in which you exercise control over both the tasks to which and circumstances under which students must respond. Constructed response and essay items are the formats of structured tasks, which permit students not only to record their answers but also to give explanation, articulate their reasoning, and express their own approaches toward solving a problem. Sometimes, the main focus is on the written product. At other time, the focus may be also on the process the students use. On-Demand Tasks; deciding what and when materials should be used, specifying the instruction for performance, describing the outcomes toward which students should work, telling the students they are being assessed, giving students opportunities to prepare themselves for the assessment. On-demand performances are naturally occurring performances in which teacher observes and assesses students in natural settings. On-demand tasks require students to perform or to do something with equipment and resources rather than write about how to do it. In some academic subjects, performing a non paper pencil tasks might be a more direct and preferred option than using a written response, even though either could be done.

2. Naturally Occurring or Typical Performance Tasks

Assessing students through observation.

3. Longer Term Projects

There are three types of Longer Term Projects, they are individual student projects, group projects, and combining group and individual projects.

Individual projects is a long-term student' activity that result in a student' product. The projects require the students to apply and integrate a wide range of abilities and knowledge. The student also requires to engage in critical 
thinking, creative thinking, and problem solving.

Group projects require two or more students to work together. The major purpose of a group projects as an assessment technique is to evaluate whether students can work together in cooperative an appropriate ways to create a high-quality product.

In a Combined Group and Individual Projects, groups of students work on a long-term project together, and after the group activities are completed, individuals prepare their own reports without the assistance of the other group members. It is useful when the project is complex and requires the collaborative talents of several students to complete in a reasonable timeframe, yet the learning target requires that individual student have the ability to prepare final reports, interpret the result on their own, and so on.

4. Portfolios

It is a limited collection of a student's work that is used to either present the student's best work or demonstrate the students' educational growth over a given time span.

A best-work portfolio focuses on presenting for assessment a students' best final product. A growth and learning-progress portfolio is used to monitor a student's learning and thinking progress, to diagnose learning and thinking difficulties, and to guide new learning and thinking.
5. Demonstrations

It is an on demand performance in which a student shows he can use knowledge and skills to complete a well-defined, complex task. Demonstrations are usually closed-responsed tasks.

6. Experiments

It is another on-demand performance which requires students to plan, conduct, and interpret the results of an empirical research. The research focuses on answering specific research questions or on investigating specific research hypotheses. It includes a wide range of research activities that occur in both natural and social science disciplines.

7. Oral Presentations and Dramatizations

Oral Presentations permit students to verbalize their knowledge and use their oral skills in the form of interviews, speeches, or oral presentations.

Debates are special type of oral performance, which pit one student against one another to logically argue issues.

Dramatizations combine verbalizations, oral and elocution skills, and movements performances. Dramatizations require students to dramatize fictional characters or historical persons by acting a role showing ideological positions and personal characteristics of these persons.

8. Simulations and Contrived Situation 
There are four formats of Simulations and Contrived Situation, they are actor and "standardized patient", computerized adaptive audiovisual scenarios, computerized adaptive text scenarios, and computerized audiovisual simulations.

In actor and "standardized patient", simulations are ondemand events that happen under controlled conditions and attempt to mimic naturally occurring events. The performance to be evaluated is the ability to interact with other person. Originally, standardized patient format was used to assess the clinical skills of medical candidates and practicing doctors. The actor is trained to display the symptoms of a particular disorder by interviewing the standardized patient to diagnose the illness and to prescribe the treatment.

Computerized

Adaptive Audiovisual Scenarios; combining technologies of video, CD-ROOM, audio, and computers to present realistic situations to students. The students are asked to response to these presentations (realistic situations given). Each student receives different scenario, depending on his or her choices of action.

Computerized Adaptive Text Scenarios is similar to the adaptive audiovisual scenario format, except that text displays replace multimedia presentation.
Computerized Audiovisual Simulations;

In short, the types of performance assessment offers by Nitko Anthony Jcan be seen in the following table.

Table2.2. Types of performance assessment

\begin{tabular}{|c|c|c|}
\hline No & $\begin{array}{l}\text { Performance } \\
\text { Assessment }\end{array}$ & Format \\
\hline \multirow[t]{2}{*}{1} & Structured Tasks & $\begin{array}{l}\text { Paper and Pencil } \\
\text { Test } \\
\text { (Contrsucted } \\
\text { Response and } \\
\text { Essay Items) }\end{array}$ \\
\hline & On-Demand Tasks & $\begin{array}{l}\text { Tasks Requiring } \\
\text { other equipment } \\
\text { and resources }\end{array}$ \\
\hline 2 & $\begin{array}{l}\text { Naturally Occuring or } \\
\text { Typical Performance } \\
\text { Tasks }\end{array}$ & Obeservation \\
\hline \multirow[t]{3}{*}{3} & \multirow[t]{3}{*}{ Longer-Term Projects } & $\begin{array}{l}\text { Individual } \\
\text { Students Projects }\end{array}$ \\
\hline & & Group Projetcs \\
\hline & & $\begin{array}{l}\text { Combining } \\
\text { Group and } \\
\text { Individual } \\
\text { Projects }\end{array}$ \\
\hline \multirow[t]{2}{*}{4} & \multirow[t]{2}{*}{ Portfolios } & $\begin{array}{l}\text { Best-work } \\
\text { Portfolios }\end{array}$ \\
\hline & & $\begin{array}{ll}\text { Growth and } \\
\text { Learning- } \\
\text { progress } \\
\text { Portfolio }\end{array}$ \\
\hline 5 & Demonstrations & \\
\hline 6 & Experiments & \\
\hline 7 & $\begin{array}{l}\text { Oral Presentation and } \\
\text { Dramatizations }\end{array}$ & \\
\hline \multirow[t]{3}{*}{8} & \multirow[t]{3}{*}{$\begin{array}{l}\text { Simulation and } \\
\text { Contrived Situations }\end{array}$} & $\begin{array}{l}\text { Actors and } \\
\text { Standardized } \\
\text { Patient }\end{array}$ \\
\hline & & $\begin{array}{l}\text { Computerized } \\
\text { Audiovisual } \\
\text { Text Scenarios } \\
\end{array}$ \\
\hline & & $\begin{array}{l}\text { Computerized } \\
\text { Adaptive Text } \\
\text { Scenarios }\end{array}$ \\
\hline
\end{tabular}




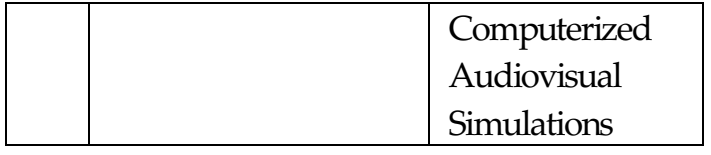

Adopted from Nitko (2004: 244)

\section{METHOD}

This study was designed as a descriptive qualitative research, in which it took in phenomenology form of research, and the research was about to describe and figure out the types of authentic assessment implemented by the EFL teachers at MA DI PUTRA NURUL HAKIM. McMillan and Schumacher (2010:346) state that this research aims at describing and interpreting the experiences of participants considering a particular event or phenomenon to understand the participants' meanings they construct from those experiences. Document study, observation and interview were conducted to get the data.

\section{Findings}

The discussion about the implementation of authentic assessment by the EFL Teachers at MA DI PUTRA NURUL HAKIM were divided into three; 1) implementation of authentic assessment by the first year EFL Teachers, 2) implementation of authentic assessment by the second year EFL Teachers, and 3) implementation of authentic assessment by the third year EFL Teachers.

\subsubsection{The Tenth Grade EFL Teachers' Assessment Practice}

There were some types of authentic assessment used by the tenth grade EFL teacher to assess their students in the classroom. The types of authentic assessment employed were writing samples, demonstration, and Oral Presentations and Dramatizations. These three types of assessment were implemented repeatedly and integrated in assessing students four skills according to the material taught. In short, the use of these types of authentic assessment in assessing students' progresses can be seen in the table bellow.

Table4.7. Type of authentic assessment implemented by the tenth grade teacher

\begin{tabular}{|c|c|c|c|}
\hline $\begin{array}{l}\mathrm{N} \\
\mathrm{O}\end{array}$ & Skill & $\begin{array}{l}\text { Assessment } \\
\text { Type }\end{array}$ & Material \\
\hline \multirow[t]{6}{*}{1} & Writing & $\begin{array}{l}\text { Writing } \\
\text { samples }\end{array}$ & $\begin{array}{l}\text { Imperative, } \\
\text { must, and } \\
\text { mustn't }\end{array}$ \\
\hline & & $\begin{array}{l}\text { Writing } \\
\text { samples }\end{array}$ & $\begin{array}{l}\text { Procedural } \\
\text { text (in group) }\end{array}$ \\
\hline & & $\begin{array}{l}\text { Writing } \\
\text { samples }\end{array}$ & $\begin{array}{l}\text { Procedural } \\
\text { text (last } \\
\text { homework) }\end{array}$ \\
\hline & & $\begin{array}{l}\text { Writing } \\
\text { samples }\end{array}$ & $\begin{array}{l}\text { Making } \\
\text { orientation, } \\
\text { complication, } \\
\text { and } \\
\text { resolution of a } \\
\text { narrative text }\end{array}$ \\
\hline & & $\begin{array}{l}\text { Writing } \\
\text { samples }\end{array}$ & $\begin{array}{l}\text { Continuing a } \\
\text { story the } \\
\text { teacher } \\
\text { started }\end{array}$ \\
\hline & & $\begin{array}{l}\text { Writing } \\
\text { samples }\end{array}$ & $\begin{array}{l}\text { Making Oral } \\
\text { Presentations } \\
\text { and } \\
\text { Dramatizatio } \\
\text { ns about } \\
\text { disbelieve } \\
\text { expression } \\
\text { (dialogue) }\end{array}$ \\
\hline \multirow[t]{3}{*}{2} & $\begin{array}{l}\text { Speakin } \\
\mathrm{g}\end{array}$ & $\begin{array}{l}\text { Demonstratio } \\
\mathrm{n}\end{array}$ & $\begin{array}{l}\text { The } \\
\text { procedural } \\
\text { text }\end{array}$ \\
\hline & & $\begin{array}{l}\text { Demonstratio } \\
\mathrm{n}\end{array}$ & $\begin{array}{l}\text { The } \\
\text { procedural } \\
\text { text }\end{array}$ \\
\hline & & $\begin{array}{l}\text { Oral } \\
\text { Presentations }\end{array}$ & $\begin{array}{l}\text { Congratulatio } \\
\mathrm{n}\end{array}$ \\
\hline
\end{tabular}




\begin{tabular}{|l|l|l|l|}
\hline & & $\begin{array}{l}\text { and } \\
\text { Dramatizatio } \\
\text { ns }\end{array}$ & \\
\hline & & $\begin{array}{l}\text { Oral } \\
\text { Presentations } \\
\text { and } \\
\text { Dramatizatio } \\
\text { ns }\end{array}$ & \\
\hline 3 & Reading & $\begin{array}{l}\text { Assessed } \\
\text { through some } \\
\text { essay }\end{array}$ & \\
\hline 4 & $\begin{array}{l}\text { Listenin } \\
\text { g }\end{array}$ & $\begin{array}{l}\text { Oral } \\
\text { questions }\end{array}$ & \\
\hline & & Cloze test & \\
\hline
\end{tabular}

From the table above, it can be seen that the teacher used writing samples repeatedly. The first writing sample was used to assess students understanding about imperative, must, and mustn't. The teacher asked the students to make some examples according to the pictures given by using imperative, must, and mustn't.In assessing speaking, the teacher implemented demonstration and Oral Presentations and Dramatizations repeatedly. Demonstration was used when the teacher assessed the students understanding about procedural text by asking the students to make a procedure of how to make some foods. The second demonstration was about something which was more complicated, that was about how to make Facebook or email.

Oral Presentations and Dramatizations was used when it came to the transactional conversation (the materials were about the expression). The first Oral Presentations and Dramatizations was used for congratulation expression, and the second Oral Presentations and Dramatizations was used for disbelieve/believe expression. It was implemented by asking students (in pair) to make a dialogue by using those expression.

The most assessment type used by the teacher was writing samples. It was used five times in the classroom assessment. The second most were Oral Presentations and Dramatizations and demonstration in which they were used twice in the classroom assessment. The next was reading aloud, constructed response items, peer assessment, drama, and Oral Presentations and Dramatizations. Each of these types of assessment was used only once in the classroom assessment.

\subsubsection{The Eleventh Grade EFL} Teachers' Assessment Practice

There were some types of authentic assessment implemented by the eleventh grade EFL teacher to assess students in the classroom. The types of authentic assessment employed were writing samples, peer assessment, reading aloud, constructed response items, story/text retelling, and Oral Presentations and Dramatizations. Some types of assessment were implemented repeatedly and integrated in assessing students four skills according to the material taught. In short, the use of these types of authentic assessment in assessing students' progress can be seen in the table bellow.

Table4.8. Type of authentic assessment implemented by the eleventh grade teacher

\begin{tabular}{|c|c|l|l|}
\hline $\begin{array}{c}\mathrm{N} \\
\mathrm{o}\end{array}$ & Skill & $\begin{array}{c}\text { Assessment } \\
\text { Type }\end{array}$ & Material \\
\hline 1 & Writing & $\begin{array}{l}\text { Writing } \\
\text { samples }\end{array}$ & $\begin{array}{l}\text { Made fable (in } \\
\text { pair) }\end{array}$ \\
\hline
\end{tabular}




\begin{tabular}{|c|c|c|c|}
\hline & & $\begin{array}{l}\text { Writing } \\
\text { samples }\end{array}$ & Revising fable \\
\hline & & $\begin{array}{l}\text { Writing } \\
\text { samples }\end{array}$ & $\begin{array}{l}\text { Oral } \\
\text { Presentations } \\
\text { and } \\
\text { Dramatizatio } \\
\text { ns }\end{array}$ \\
\hline & & $\begin{array}{l}\text { Writing } \\
\text { samples }\end{array}$ & $\begin{array}{l}\text { Made Oral } \\
\text { Presentations } \\
\text { and } \\
\text { Dramatizatio } \\
\text { ns }\end{array}$ \\
\hline & & $\begin{array}{l}\text { Peer } \\
\text { assessment }\end{array}$ & $\begin{array}{l}\text { Exchanging } \\
\text { the fable } \\
\text { made }\end{array}$ \\
\hline 2 & $\begin{array}{l}\text { Speakin } \\
\mathrm{g}\end{array}$ & $\begin{array}{l}\text { Reading } \\
\text { aloud }\end{array}$ & Narrative text \\
\hline & & Story telling & $\begin{array}{l}\text { Retelling the } \\
\text { fable made }\end{array}$ \\
\hline & & Story telling & Spoof \\
\hline & & $\begin{array}{l}\text { Oral } \\
\text { presentations } \\
\text { and } \\
\text { Dramatizatio } \\
\text { ns }\end{array}$ & $\begin{array}{l}\text { Performing a } \\
\text { fable (drama) }\end{array}$ \\
\hline & & $\begin{array}{l}\text { Oral } \\
\text { Presentations } \\
\text { and } \\
\text { Dramatizatio } \\
\text { ns } \\
\end{array}$ & $\begin{array}{l}\text { Performing a } \\
\text { dialogue } \\
\text { about } \\
\text { Embarrassme } \\
\text { nt }\end{array}$ \\
\hline 3 & Reading & $\begin{array}{l}\text { Reading } \\
\text { aloud }\end{array}$ & Narrative text \\
\hline & & $\begin{array}{l}\text { Constructed } \\
\text { response } \\
\text { items }\end{array}$ & $\begin{array}{l}\text { Open ended } \\
\text { questions } \\
\text { about past } \\
\text { tense }\end{array}$ \\
\hline 4 & $\begin{array}{l}\text { Listenin } \\
\mathrm{g}\end{array}$ & $\begin{array}{l}\text { Through } \\
\text { speaking by } \\
\text { asking some } \\
\text { questions and } \\
\text { asked the } \\
\text { students to } \\
\text { respond to it } \\
\text { orally }\end{array}$ & \\
\hline
\end{tabular}

From the table above it can be seen that the teacher implemented more than one type of assessment to assess one single skill. It is proven when the teacher assessed writing, speaking, and reading skills. When assessing writing skill, the teacher used writing samples and peer assessment. Writing samples was used repeatedly to assess students writing skill, while peer assessment was used when the teacher asked the students to find out some mistakes done by their friends in their writing work. The students were asked to list some mistake (in this sense, the past verb) and asked to give some explanation about the mistake.

Speaking was assessed by using reading aloud, drama, story telling, and Oral Presentations and Dramatizations. Reading aloud was used by asking the students to read a text loudly. In here, the teacher corrected the students' pronunciation. Drama was used when the students were asked to perform a story. Story telling was used by asking the students to retell the story (fable) they had made. Oral Presentations and Dramatizations was used by asking the students to perform the Oral Presentations and Dramatizations they made.

Reading was assessed through reading aloud and constructed response item. Through reading aloud, the teacher would get the information how a students pronounced words. It was conducted by integrating with speaking. Constructed response items was used by providing some open ended questions, then asked the students to answer by giving some explanation which was logic and reasonable in their own words.For listening, the teacher assessed it through speaking by asking the students some questions and then expected them to answer orally.

The most assessment type used by the teacher was writing samples. It was 
used four times in the classroom assessment. The second most was story/text retelling in which it was used twice in the classroom assessment. The next was reading aloud, constructed response items, peer assessment, drama, and Oral Presentations and Dramatizations. Each of these types of assessment was used only once in the classroom assessment.

\subsubsection{The Twelfth EFL Teachers' Assessment Practice}

There were some types of authentic assessment used by the twelfth EFL teacher to assess students understanding in the classroom. The types of authentic assessment employed were writing samples, presentation, tell/text retelling, and Oral Presentations and Dramatizations. Some types of assessment were implemented repeatedly and integrated in assessing students four skills according to the material taught. In short, the use of these types of authentic assessment in assessing students' progress can be seen in the table bellow.

Table 4.9. Type of authentic assessment implemented by the twelfth grade teacher

\begin{tabular}{|c|c|l|l|}
\hline $\begin{array}{c}\text { N } \\
\mathrm{o}\end{array}$ & Skill & \multicolumn{1}{|c|}{$\begin{array}{c}\text { Assessment } \\
\text { Type }\end{array}$} & \multicolumn{1}{|c|}{ Material } \\
\hline 1 & Writing & $\begin{array}{l}\text { Writing } \\
\text { samples }\end{array}$ & $\begin{array}{l}\text { Making Oral } \\
\text { Presentations } \\
\text { and } \\
\text { Dramatizatio } \\
\text { ns of planning }\end{array}$ \\
\hline & & $\begin{array}{l}\text { Writing } \\
\text { samples }\end{array}$ & Narrative text \\
\hline & & $\begin{array}{l}\text { Writing } \\
\text { samples }\end{array}$ & $\begin{array}{l}\text { Conversation } \\
\text { of review text }\end{array}$ \\
\hline & & $\begin{array}{l}\text { Writing } \\
\text { samples }\end{array}$ & Review text \\
\hline
\end{tabular}


In sum, the assessment practice can be seen in the table below;

The table 4.10. Table of the percentage of authentic assessment practiced by the EFL teachers

\begin{tabular}{|c|c|c|c|c|}
\hline $\begin{array}{l}\mathrm{N} \\
\mathrm{O}\end{array}$ & $\begin{array}{c}\text { Types of } \\
\text { assessment }\end{array}$ & Skill & $\begin{array}{c}\text { Freque } \\
\text { ncy }\end{array}$ & $\begin{array}{l}\text { Percent } \\
\text { age (\%) }\end{array}$ \\
\hline 1 & $\begin{array}{l}\text { Constructe } \\
\text { d response } \\
\text { items }\end{array}$ & $\begin{array}{l}\text { Readi } \\
\text { ng }\end{array}$ & 1 & $3.45 \%$ \\
\hline \multirow[t]{2}{*}{2} & \multirow[t]{2}{*}{$\begin{array}{l}\text { Reading } \\
\text { aloud }\end{array}$} & $\begin{array}{l}\text { Readi } \\
\text { ng }\end{array}$ & \multirow[t]{2}{*}{1} & $3.45 \%$ \\
\hline & & $\begin{array}{l}\text { Speaki } \\
\text { ng }\end{array}$ & & \\
\hline \multirow[t]{3}{*}{3} & \multirow[t]{3}{*}{$\begin{array}{l}\text { Story/text } \\
\text { retelling }\end{array}$} & $\begin{array}{l}\text { Speaki } \\
\text { ng }\end{array}$ & \multirow[t]{3}{*}{5} & $17.24 \%$ \\
\hline & & $\begin{array}{l}\text { Readi } \\
\text { ng }\end{array}$ & & \\
\hline & & $\begin{array}{l}\text { Writin } \\
\mathrm{g}\end{array}$ & & \\
\hline 4 & $\begin{array}{l}\text { Peer } \\
\text { assessment }\end{array}$ & $\begin{array}{l}\text { Writin } \\
\mathrm{g}\end{array}$ & 1 & $3.45 \%$ \\
\hline \multirow[t]{2}{*}{5} & \multirow[t]{2}{*}{$\begin{array}{l}\text { Demonstra } \\
\text { tion }\end{array}$} & $\begin{array}{l}\text { Writin } \\
\mathrm{g}\end{array}$ & \multirow[t]{2}{*}{2} & $6.89 \%$ \\
\hline & & $\begin{array}{l}\text { Speaki } \\
\text { ng }\end{array}$ & & \\
\hline \multirow[t]{2}{*}{6} & $\begin{array}{l}\text { Oral } \\
\text { Presentatio } \\
\mathrm{ns} \text { and } \\
\text { Dramatizat } \\
\text { ions }\end{array}$ & $\begin{array}{l}\text { Speaki } \\
\text { ng }\end{array}$ & 5 & $17.24 \%$ \\
\hline & & $\begin{array}{l}\text { Writin } \\
\mathrm{g}\end{array}$ & & \\
\hline 7 & $\begin{array}{l}\text { Writing } \\
\text { samples }\end{array}$ & $\begin{array}{l}\text { Writin } \\
\mathrm{g}\end{array}$ & 14 & $48.27 \%$ \\
\hline \multicolumn{2}{|c|}{ Average } & & 29 & $100 \%$ \\
\hline
\end{tabular}

Based on the data displayed in the table above, it can be seen that the researcher implemented types of authentic assessment based on O'Malley \& Pierce (1996) and Nitko (2004) classification such as writing samples, oral presentations and dramatizations (drama and dialogue), story/text retelling, demonstration, reading aloud, peer assessment, and constructed response items.

From the table above, it can be seen the EFL teachers integrated one skill to another in classroom assessment. They also integrated one type of authentic assessment with other type in assessing one skill. The most authentic assessment type used was writing samples, it was used repeatedly. The frequency of writing samples was $48.27 \%$. the second most were story/text retelling, $17.24 \%$ and Oral Presentations and Dramatizations with the frequency of used $13.79 \%$. The next was demonstration with the frequency about $6.89 \%$. The least were reading aloud, peer assessment, and constructed response items. Each of these assessment type was used only once with the frequency about $3.45 \%$.

\section{CONCLUSION}

There were six types of authentic assessment practiced by the teachers. They were writing samples, Oral Presentations and Dramatizations, demonstration, story/text retelling, reading aloud, constructed response items, and peer-assessment. These seven types of authentic assessment were used to assess the students' four skills. This finding is as same as what have already been found by previous researchers. In assessing one skill, the teachers integrated it with other skills. Besides, the EFL teachers also used one single assessment type in assessing more than one skills. As they are integrated, children seek and construct meaning as they read, write, and discuss ideas in authentic context. 


\section{REFERENCES}

Black, P., \&Wiliam, D. (2006).Assessment for learning in the classroom.In J. Gardner (ed.), Assessment and Learning. London: Sage Publications Ltd.

Kusumadinata, I.W.W. (2010). “Developing Performance Assessment of Reading Skill of the Tenth Grade of Smk Students in Second Semester in Tabana Regency". (Unpulished Thesis). Singaraja: Undiksha

Macmillan. (1996). Handbook of Research for Educational Communications and Techonology. New York: Prentice Hall International.

Marhaeni, A.A.I.N. (2005). Pengaruh Asesmen Portofolio dan Motivasi Berprestasi dalam Belajar Bahasa Inggris terhadap Kemampuan Menulis dalam Bahsa Inggris: StudiEksperimenpadaMahasiswaJ urusanPendidikanBahsaInggris IKIP NegeriSingaraja, 2004. (Unpublished Disertation). Jakarta: University of Jakarta
Masidjo. (2007). Penilaian Hasil Pencapain Belajar Siswa di Sekolah (8th ed). Yogyakarta: Kanisius.

McMillan, James H., and Sally Schumacher. (2010). Research in Education: Evidence-Based Inquiry, $7^{\text {th }}$ Edition. New Jersey: Pearson Education Inc.

Nitko, A.J. (2004). Performance, portfolio, and authentic assessments: An Overview. Educational Assessment of Students. Columbus, Ohio: Pearson.

O’Malley, J.M., L. Valdez Pierce. (1996). Authentic Assessment for English Language Leraners: Practical Approaches for Teachers. Addison-Wesley Publishing 